\title{
Prevalence of influenza and adherence to the anti-flu vaccination among elderly
}

\author{
Eduardo Yukio Nakamura ${ }^{[1]}$, Luane Marques de Mello ${ }^{[2]}$, Anderson Soares da Silva ${ }^{[2]}$ \\ and Altacílio Aparecido Nunes ${ }^{[2]}$
}

[1]. Curso de Medicina, Faculdade de Medicina de Ribeirão Preto, Universidade de São Paulo, Ribeirão Preto, SP. [2]. Departamento de Medicina Social, Faculdade de Medicina de Ribeirão Preto, Universidade de São Paulo, Ribeirão Preto, SP.

\begin{abstract}
Introduction: The flu, a condition that can affect the elderly by increasing the risk of serious complications can be prevented through vaccination. Estimate the prevalence of signs and symptoms suggestive of influenza in a group of elderly either vaccinated or unvaccinated against influenza was the objective this study. Methods: This is a cross-sectional study performed in a Brazilian City. A structured questionnaire was employed to identify the presence of signs and symptoms of influenza in individuals aged 60 years or over. For analysis of associations between variables the prevalence ratio (PR) and its $95 \%$ confidence interval $(95 \% \mathrm{Cl})$ were used. Results: One hundred ninety-six participants were interviewed, of whom $57.7 \%$ were female. The average age was 69.7 years. About $25 \%$ of the vaccinated and $20 \%$ of the unvaccinated in 2009 , and $25 \%$ of the vaccinated and $22.5 \%$ of the unvaccinated in 2010 reported having the flu. Among the vaccinated and unvaccinated in 2009 and 2010, there was no verified association between vaccination and influenza ( $P R=1.24$; [95\% Cl: 0.63-2.43] and $\mathrm{PR}=1.11 ;$ [ $95 \% \mathrm{Cl}: 0.59-2.09]$, respectively). Conclusions: This study suggests that, among the elderly selected, the vaccination coverage for influenza is below the ideal, even with projection of the best indices for 2011 ( 84\%). The data on vaccination and disease protection needs further research; however, the results point to the need for measures to better clarify to this population about the disease, its complications and the benefits of vaccination, in addition to combatting the stigma related to low adherence.
\end{abstract}

ABSTRACT

Keywords: Elderly health. Anti-flu vaccine. Adherence. Influenza virus.

\section{INTRODUCTION}

Each year, influenza and its complications cause high rates of hospital admissions, deaths and costs to health services worldwide, mainly due to the severe form of the disease that occurs in elderly people. As an influenza outbreaks spread rapidly during the epidemic, it is responsible for high morbidity and mortality in the elderly, who are easy targets for serious complications of the disease, such as pneumonia, resulting in months of hospitalization ${ }^{1-3}$.

Studies have shown vaccination of older people to be an effective tool against complications of this disease. Many authors point out that, despite the drugs already available for treatment, to vaccinate is still the best tool for prevention and complications of influenza in the elderly 4 .

In Brazil each year, the flu reaches $20 \%$ of the elderly population, and in this age group vaccination can prevent and reduce morbidity and mortality associated with disease ${ }^{5,6}$. In order to protect the groups at greatest risk for complications of influenza (the elderly and those with chronic diseases), the Brazilian Ministry of Health has implemented anti-influenza vaccination since 1999.

In old age, the protective effect of the influenza vaccine can be affected by the immune response of the individualism addition to the immunogenicity of the vaccine and the antigenic match between the vaccine and the strains present in the social environment ${ }^{7-10}$. Despite

Address to: Prof. Altacílio Aparecido Nunes. Depto de Medicina Social/FMRP/USP. Av. Bandeirantes 3900, Monte Alegre, 14049-900 Ribeirão Preto, SP, Brasil.

Phone: 5516 3602-2569

e-mail: altacilio@fmrp.usp.br

Received in 12/09/2011

Accepted in 30/10/2012 offering immunity that varies between 30 and $70 \%$, vaccination promotes the prevention of primary viral pneumonia and secondary bacterial pneumonia in 50 to $60 \%$ of those vaccinated, decreases hospitalizations by $50 \%$ and reduces mortality by $80 \%$. Importantly, the vaccine's effectiveness also depends on its composition and immunobiological coincidence with the strains actually circulating during the season ${ }^{11}$. Still there is little doubt about the effects of vaccination in developed countries; studies have shown the influenza vaccine causes a reduction in mortality in the elderly by $50 \%$. In addition, they found a reduction in risk of hospitalizations for heart disease of $19 \%$ and for cerebrovascular events of up to $23 \%$.

Nowadays there is worldwide concern about the prevention of diseases that affect the daily activities of the elderly and the flu represents a major one. The complications of influenza are more common in elderly and debilitated people and are considered a hazard to people with chronic lung disease (asthma and chronic obstructive pulmonary disease - COPD), heart disease (chronic heart failure), chronic metabolic disease (diabetes and other), immunodeficiency or immunosuppression, chronic kidney disease and hemoglobinopathies. Secondary bacterial pneumonias, especially those caused by Streptococcus pneumoniae, Staphylococcus sp and Haemophillus influenzae type B and non-typable, are among the most common pulmonary complications in elderly patients with influenza ${ }^{12-16}$.

With regard to adverse events from the vaccine, Francisco et al. ${ }^{17}$ explain that since the introduction of highly purified complete virus vaccines, reactions have decreased significantly but local manifestations of pain, swelling, erythema or nodule at the injection site may be present in 15 to $20 \%$ of cases, lasting one to two days in $1 \%$ of cases. Systemic reactions such as fever, malaise and myalgia can also occur, usually 6 to 12 hours after vaccination, lasting one to two days. Hypersensitivity reactions, anaphylaxis and neurological manifestations are extremely rare ${ }^{18-21}$. 
Based on the exposed, the purpose of this study was to estimate the prevalence, in 2009 and 2010, of flu among both vaccinated and unvaccinated, and verify adherence to the immunization procedure in individuals 60 years old and older, resident in areas of the Family Health Unit in districts of the City of Ribeirão Preto, State of São Paulo, Brazil.

\section{METHODS}

This was a cross-sectional study, from 196 respondents, conducted in the period from April 2010 to April 2011, in two Family Health Units (FHU) of the Faculty of Medicine of Ribeirão Preto (FHU 3 and FHU 4), University of São Paulo (FMRPUSP), Brazil.

An interview was performed by a trained medical student present at the Health Unit two days a week over 12 months. Any user presented in the Health Unit at the time of the interview, who had full the inclusion criteria, was invited to participate in the study. Information was collected about such sociodemographic aspects as sex, age, marital status, education level and monthly family income of the respondents, and they were asked to sign the free consent form.

Data considered relevant to the study were obtained from the reports of the respondents about their perceptions of their health status, their opinions regarding influenza vaccination, the number of times they had been affected by the disease and its effects (hospitalizations, activity limitations, etc). The presence of signs and symptoms of the disease was used to characterise the occurrence or not of flu ${ }^{14,15}$.

\section{Inclusion and exclusion criteria}

Individuals were included from both sexes, aged 60 years or older, with no signs or symptoms suggestive of respiratory airway disease (lower and upper), who agreed to participate in the study. Patients who did not agree to participate and those where influenza vaccination was contraindicated were excluded from the study.

\section{Statistical analysis}

To calculate the sample size, the size of the population of individuals aged 60 years or older resident in the FHU 3 and FHU 4 enrollment, area considered to be about 3,000 individuals, was taken into account, the prevalence of flu (mean of $15 \%$ according to literature $)^{10}$ and a tolerance of $5 \%$ with a confidence coefficient of $95 \%$, which resulted in a minimum sample size of 184 people. The chi-squared test was used to analyse the differences in proportions between the variables. The Student's t-test was used in the analysis of independent samples to assess the differences means. The prevalence ratio (PR) and its $95 \%$ confidence interval $(95 \% \mathrm{Cl})$ were used as an estimator of the degree of association between selected variables. A significance level of $5 \%$ was considered for all analyses.

\section{Ethical aspects}

The Research Project was approved by the Research Ethics Committee of the Institution. Participants were included in the study only after reading, agreeing with and signing the Free and Informed Consent Term.

\section{RESULTS}

Data were obtained from 196 respondents ranging in age from 60 to 92 years old (mean 69.7 and median 70 years old). About $57 \%$ were female, $55.1 \%$ were married, $28.1 \%$ were widowed, $8.6 \%$ were divorced and $8.2 \%$ were single. With respect to ethnicity, $87.3 \%$ were white, $11.2 \%$ black and $1.5 \%$ were of Asian descent. The question about education level showed that $54.6 \%$ had not finished elementary school, only $5.6 \%$ had concluded higher education, and 3.5\% were illiterate (Table 1).

Their monthly income ranged from no income at all (1 person) to a high of $R \$ 5,000.00$ in the Brazilian currency (1 person). The average income (Table 2) among the interviewees was $R \$ 1,442.00$ among the women, and $\mathrm{R} \$ 1,409.76$ among men, with no associations between this variable and gender $(p>0.05)$. When the variable income was compared to adherence to vaccination an average of $\mathrm{R} \$ 1,393.18$ in 2009 and $R \$ 1,452.04$ in 2010 was found among vaccinated individuals, compared to $\mathrm{R} \$ 1,575.54$ (2009) and $\mathrm{R} \$ 1,330.66$ (2010) among the

TABLE 1 - Distribution of sociodemographic variables of selected subjects aged $\geq 60$ years old.

\begin{tabular}{|c|c|c|}
\hline Variables & Number & Percentage \\
\hline \multicolumn{3}{|l|}{ Gender } \\
\hline male & 83 & 42.3 \\
\hline female & 113 & 57.7 \\
\hline Total & 196 & 100.0 \\
\hline \multicolumn{3}{|l|}{ Ethnicity } \\
\hline white & 171 & 87.3 \\
\hline black & 9 & 4.6 \\
\hline brown & 13 & 6.6 \\
\hline yellow & 3 & 1.5 \\
\hline Total & 196 & 100.0 \\
\hline \multicolumn{3}{|l|}{ Marital status } \\
\hline married & 108 & 55.1 \\
\hline single & 16 & 8.2 \\
\hline widower & 55 & 28.1 \\
\hline divorced & 17 & 8.6 \\
\hline Total & 196 & 100.0 \\
\hline \multicolumn{3}{|l|}{ Education level } \\
\hline incomplete primary education & 114 & 58.1 \\
\hline complete primary education & 46 & 23.5 \\
\hline high school graduates & 19 & 9.7 \\
\hline incomplete college & 6 & 3.1 \\
\hline college graduates & 11 & 5.6 \\
\hline Total & 196 & 100.0 \\
\hline
\end{tabular}

TABLE 2 - Distribution of income related to gender and vaccine status in 2009 and 2010 among selected elderly.

\begin{tabular}{lcc}
\hline Variable & Mean of income $( \pm S D)$ & \\
\hline $\begin{array}{l}\text { Gender } \\
\text { male }\end{array}$ & $p=0.15$ \\
female & $1,409.76( \pm 879.80)$ & \\
\hline Vaccine - 2009 & $1,442.01( \pm 1,061.74)$ & \\
yes & $1,393.18( \pm 969.48)$ & \\
no & $1,575.54( \pm 1,050.37)$ & \\
\hline Vaccine - 2010 & & \\
yes & $1,452.04( \pm 1,026.20)$ & \\
no & $1,330.66( \pm 801.53)$ & \\
\hline
\end{tabular}

\pm SD: standard deviation. 
non-vaccinated, with no differences between the groups ( $p>0.05$ ) (Table 2).

The distribution of sociodemographic variables in vaccinated elderly in the years 2009 and 2010 can be observed in Table 3. In 2009, overall adherence to the fluvaccine procedure was $80.1 \%$, consisting of 91 women (58\% of the respondents) and 66 men ( $42 \%$ of the respondents) $p>0.05$. In 2010, the scenario remained almost the same: overall adherence was $79.6 \%$, comprised of $57 \%$ women and $43 \%$ men ( $p>0.05)$. Also with regard to adherence, in 2009 and 2010 there were no significant differences when the level of schooling and ethnicity ( $p>0.05)$ was considered. When comparing differences between vaccinated and unvaccinated in relation to ethnicity, it is observed that white elderly showed lower prevalence of vaccination than yellow race elderly [prevalence ratio $(P R)=0.80 ; 95 \%$ confidence interval (95\% Cl): 0.74-0.86 in 2009 and PR=0.79; $95 \%$ Cl: $0.73-0.85$ in 2010], however the sample of white elderly people is much larger than the yellows, and this possibly led to significance purely statistical and no causal association. The same was observed when compared marital status in 2009, where the married showed prevalence lower of vaccination in relation to singles ( $P R=0.83$; 95\% Cl: 0.71-0.98), in other hand, in 2010 the widows showed a prevalence of lower vaccination in relation to singles ( $P R=0.80 ; 95 \% \mathrm{Cl}$ : $0.65-0.97)$. These findings cannot be explained by causal standpoint.

In general, the elderly showed symptoms of flu such as cough, weakness, coryza, and malaise. Twenty four percent of all respondents reported having flu during 2009 and 2010 . About $25 \%$ of the vaccinated and $20 \%$ of the unvaccinated in 2009 , and $25 \%$ of the vaccinated and $22.5 \%$ of the unvaccinated in 2010 reported having the flu. With regard to complications, only one (0.5\%) respondent vaccinated in 2009 and 2010 reported hospitalization for pneumonia associated with an influenza episode (Table 4). The most common symptoms associated with the flu were cough (83.3\%), rhinorrhea (52.1\%), myalgia (47.9\%) and fever (43.7\%). About $87.3 \%$ of vaccinated respondents believed that the vaccine helped in some way, either by decreasing the intensity of symptoms $(27.3 \%)$ and decreasing the frequency of episodes (25.4\%) or completely preventing a new episode of flu (21.2\%).

With regard to their perspectives on vaccination in the future, $84.7 \%$ of the respondents said they intended to get vaccinated in 2011 (Table 4). Among the reasons cited for non-adherence to the procedure, fear caused by bad experiences of others, the low priority given to the vaccine, disinterest, disbelief in its protective effect, not being aware of the vaccination period, forgetfulness and not needing the vaccine were all mentioned by the responders. The unvaccinated patients were those who felt good and did not feel vulnerable to the disease, those who did not get the flu frequently and those who did
TABLE 4 - Distribution of collected information about flu vaccine, its side effects and the presence of flu among elderly respondents.

\begin{tabular}{|c|c|c|}
\hline Variables & Number & Percentage \\
\hline \multicolumn{3}{|c|}{ Vaccinated in 2009} \\
\hline yes & 157 & 80.1 \\
\hline no & 39 & 19.9 \\
\hline \multicolumn{3}{|c|}{ Vaccinated in 2010} \\
\hline yes & 156 & 79.6 \\
\hline no & 40 & 20.4 \\
\hline \multicolumn{3}{|c|}{ Side effects* } \\
\hline yes & 9 & 5.8 \\
\hline no & 147 & 94.2 \\
\hline \multicolumn{3}{|l|}{ Flu } \\
\hline yes & 48 & 24.5 \\
\hline no & 148 & 75.5 \\
\hline \multicolumn{3}{|c|}{ Hospitalization** } \\
\hline yes & 1 & 0.5 \\
\hline no & 195 & 99.5 \\
\hline \multicolumn{3}{|c|}{ Do you think the vaccine helped? } \\
\hline yes & 144 & 87.3 \\
\hline no & 21 & 12.7 \\
\hline \multicolumn{3}{|c|}{ Intends to vaccinate in 2011? } \\
\hline yes & 166 & 84.7 \\
\hline no & 30 & 15.3 \\
\hline
\end{tabular}

*among individuals vaccinated in 2010; **hospitalizations for influenza only. 
not valorize the procedure. Among those who said they do not intend to get vaccinated in 2011, the main explanations for this were lack of interest (23.3\%), having had side effects once to the vaccine (16.7\%), not believing in the protective effect of the vaccine (16.7\%) and fear $(13.3 \%)$. Of the 167 subjects who were vaccinated at least once in 2009 or 2010, 20 (12\%) had side effects in at least one dose. Among those dissatisfied with the vaccine, the main reason mentioned was a belief in no protective effect (the vaccine do not work) because they got the flu even after have been vaccinated.

The calculation of the measure of association between the influenza vaccine and episodes of flu identified a PR $=1.24(95 \%$ $\mathrm{Cl}: 0.63-2.43$ ) in 2009 (p>0.05) and 1.11 (95\% Cl: 0.59-2.09) in 2010 $(p>0.05)$ suggesting that the flu is not less frequent among the vaccinated (Table 5).

TABLE 5 - Association between vaccination and influenza in people aged $\geq 60$ years, 2009 and 2010.

\begin{tabular}{|c|c|c|c|c|c|c|}
\hline \multirow{6}{*}{ Vaccinated 2009} & & \multicolumn{4}{|c|}{ Flu } & \multirow[b]{3}{*}{ Total } \\
\hline & & \multicolumn{2}{|c|}{ yes } & \multicolumn{2}{|c|}{ no } & \\
\hline & & $n$ & $\%$ & $n$ & $\%$ & \\
\hline & yes & 40 & 25.5 & 117 & 74.5 & 157 \\
\hline & no & 8 & 20.5 & 31 & 79.5 & 39 \\
\hline & total & & & & & 196 \\
\hline \multirow[t]{6}{*}{ Vaccinated 2010} & & \multicolumn{4}{|c|}{ Flu } & \\
\hline & & \multicolumn{2}{|c|}{ yes } & \multicolumn{2}{|c|}{ no } & \\
\hline & & $n$ & $\%$ & $n$ & $\%$ & Total \\
\hline & yes & 39 & 25.0 & 117 & 75.0 & 156 \\
\hline & no & 9 & 22.5 & 31 & 77.5 & 40 \\
\hline & total & \multicolumn{2}{|c|}{48} & \multicolumn{2}{|c|}{148} & 196 \\
\hline
\end{tabular}

2009: $P R=1.24$ (95\% Cl: $0.63-2.43), p>0.05 ; 2010: P R=1.11(95 \% \mathrm{Cl}: 0.59-2.09), p>0.05$.

\section{DISCUSSION}

Considering the benefits of the flu vaccine in the elderly, the recommendations of the Advisory Committee on Immunization Practices as part of the Healthy People program in 2010, recommended $90 \%$ coverage in the senior population as a goal to be achieved ${ }^{1}$. The improvement in flu vaccine coverage, ideally reaching $95 \%$, might reduce morbidity and prevent further complications from influenza, and could provide more effective herd immunity, rationalizing costs to the public health ${ }^{1,6}$.

The present study showed that $80 \%$ of the individuals studied, aged 60 years or older living in the City of Ribeirão Preto, State of São Paulo, had been vaccinated in 2009 or 2010 , with $84.7 \%$ stating an intent to be vaccinated in 2011. Although it should be pointed out the numbers this study are suboptimal, these results are still above the majority of the nation in terms of vaccine coverage.

By the way, an increasing coverage for the State of São Paulo has been noticed since the implementation of vaccination campaigns: $63.9 \%(2000), 66.6 \%(2001), 65.6 \%$ (2002), and $75 \%$ (2003), surpassing the initial goal of $80 \%$ vaccine coverage and a minimum incidence of complications from pneumonia. However, these numbers are still below the ideal and have also been observed in other cities in South and Southeast Brazil, such as São Paulo/SP, Rio de Janeiro/RJ, Curitiba/ $\mathrm{PR}$, and Florianópolis/SC $\mathrm{SC}^{17,18}$ that have shown coverage under $80 \%$, according recent studies ${ }^{19,20}$.
This study showed that there are some factors related to nonadherence of elderly people to vaccination campaigns that may be linked to the lower observed coverage. Better information to the elderly group about the vaccine certainly could reduce some of the frightening stigma and would probably greatly improve adherence.

Some of the vaccinated interviewees justified their resistance to the procedure by saying that they are well, do not feel vulnerable to the disease, and do not get the flu frequently. Apparently they did not valorize the procedure, probably because they felt themselves safe. We do not know how to explain these findings.

Strategies to increase immunization coverage through improved compliance were attempted in a Spanish study with good results ${ }^{22}$ using simple and inexpensive measures which could be implemented in any other country. Another suggested strategy to solve the compliance point would be to invest in home care performed by welltrained health professionals.

In this study a certain predominance (without statistical significance) of non-adherence in the subgroups of illiterates, those with higher educational levels, widowed and married were also observed. This result agrees with other studies that also showed lower vaccination rates among married individuals and those with a higher level of education ${ }^{6,17,18}$. With respect to gender, the proportion of vaccinated was very similar to the unvaccinated.

It is important to emphasize that vaccination campaigns should be more educational, informing the public that despite being a benign and preventable disease, the flu can lead to serious complications, especially for some individuals at higher risk such as those with chronic diseases and the elderly.

In addition, the Primary Health Care team, which maintains longitudinal contact with the members of the community, must be prepared to identify and guide the indication of immunization as well as demystify the alleged harm attributed to the vaccine.

The present study found no association between vaccination and reports of signs and symptoms of flu. This result seems somewhat paradoxical and suggests the need for more studies to better clarify these findings.

The efficacy of the influenza vaccine, considering all ages and all population groups, is around $89 \%$. However, there are reports that mention lower levels among the elderly in an inversely proportional relationship between age at vaccination and protection against disease. Other studies have shown that some clinical conditions often found in the elderly, such as cardiovascular disease and other chronic conditions, may also contribute to a decreased immune response to influenza vaccine. In addition, influenza is caused by a viral agent with many different serotypes, which render it a highly prevalent disease; that can also affect the rate of vaccine protection ${ }^{23-25}$.

To better discuss these data it is very important to take into account the limitations of this study. First, cross-sectional studies are not intended to evaluate vaccine efficacy. That would necessitate a more appropriate type of study such as population-based longitudinal studies.

Another important bias in this case is the possibility of recall bias, since the data were self-reported, without objective confirmation by laboratory tests. However, some authors have emphasized the validity and accuracy of information provided by the elderly with regard to 
recalling influenza vaccination ${ }^{26,27}$. Another point to be mentioned was the difficulty in differentiating a common cold from the flu by the respondents, since sometimes they were not able to specify particular symptoms or signs, or even the possibility of being induced to confirm when asked about more specific symptoms such as weakness or fever.

In any case, the data presented here contribute interesting information about the vaccination status of the elderly population of Ribeirão Preto and its perceptions with regard to this medical procedure.

In conclusion, the present study there was no association between vaccination and signs and symptoms of influenza, findings that raise questions about the protective effects of the vaccine. These are unexpected results that may be related to the occurrence of information bias, the type of study (cross-sectional study) and aspects of the disease itself, but deserve further study to be better clarified. This study showed that vaccine coverage for influenza in Ribeirão Preto, State of São Paulo may still be below the ideal, but with higher rates projected for 2011 ( $\pm 84 \%)$, and it identified some points related to low compliance that can probably explain these findings.

\section{CONFLICT OF INTEREST}

The authors declare that there is no conflict of interest.

\section{ABSTRACT IN PORTUGUESE}

\section{Prevalência de gripe e aderência à vacinação anti-influenza entre idosos}

Introdução: A gripe, condição que pode afetar a saúde dos idosos aumentando o risco de complicações graves pode ser prevenida por meio de vacina. 0 objetivo deste estudo foi estimar a prevalência de sinais e sintomas sugestivos de gripe em um grupo de idosos vacinados e não vacinados contra influenza. Métodos: Estudo transversal realizado em uma cidade brasileira. Usou-se questionário estruturado para identificar presença de sinais e sintomas de gripe em indivíduos com idade igual ou maior de 60 anos. Para análise de associação entre variáveis empregou-se a razão de prevalência e seu intervalo de confiança a $95 \%$. Resultados: Dos 196 participantes, 57,7\% eram do sexo feminino e a média de idade foi 69,7 anos. Aproximadamente, $25 \%$ dos vacinados e $20 \%$ dos não vacinados em 2009 e $25 \%$ dos vacinados e $22,5 \%$ dos não vacinados em 2010, relataram sinais e sintomas de gripe. Entre os vacinados e não vacinados, em 2009 e 2010, não foi verificada associação entre vacinação e gripe (RP = 1,24; [IC 95\%: 0,63-2,43] e RP = 1,11; [IC95\%: 0,59-2,09]), respectivamente). Conclusões: 0 estudo sugere que, entre os idosos estudados, a cobertura vacinal para a gripe encontra-se abaixo do ideal, com projeção de melhores índices para 2011 ( $\pm 84 \%)$. Os dados sobre a vacinação e proteção contra a doença carece de novas pesquisas, entretanto, os resultados apontam para necessidade de medidas para esclarecer melhor a população sobre a doença, suas complicações e benefícios da vacinação, além de combater estigmas relacionados à baixa adesão.

Palavras-chaves: Saúde do idoso. Vacinação anti-gripe. Aderência. Vírus Influenza.

\section{REFERENCES}

1. Broder K, Iskander JK, Uyeki TM, Mootrey G, Bresee JS, Cox NS, Centers for Disease Control and Prevention (CDC), Advisory Committee on Immunization Practices (ACIP). Prevention and control of influenza: recommendations of the Advisory Committee on Immunization Practices (ACIP), 2008. MMWR Recomm Rep 2008; 57:1-60.

2. Owen R, Barr IG, Pengilley A, Liu C, Paterson B, Kaczmarek M, Surveillance Scheme. Annual report of the National Influenza Surveillance Scheme, 2007. Commun Dis Intell 2008; 32:208-226.
3. Firestone SM, Barr IG, Roche PW, Walker JC. Annual report of the National Influenza Surveillance Scheme, 2005. Commun Dis Intell 2006; 30:189-200.

4. Bellei N, Carraro E, Perosa A, Watanabe A, Arruda E, Granato C. Acute respiratory infection and influenza-like illness viral etiologies in Brazilian adults. J Med Virol 2008; 80:1824-1827.

5. Cordeiro R, Ruiz $\mathrm{T}$, Donalisio $M R$. Fatores associados à vacinação contra influenza em idosos em município do Sudeste do Brasil. Rev Saude Publica 2006; 40:115-119.

6. Fundação Nacional de Saúde. Guia de vigilância epidemiológica. 5ạed. Brasília: FUNASA; 2002.

7. Louie JK, Hacker JK, Gonzales R, Mark J, Maselli JH, Yagi S, et al. Characterization of viral agents causing acute respiratory infection in a San Francisco University Medical Center Clinic during the influenza season. Clin Infect Dis 2005; 41:822-828.

8. Kelly $\mathrm{H}$, Birch $\mathrm{C}$. The causes and diagnosis of influenza-like illness. Aust Fam Physician 2004; 33:305-309.

9. Wallace LA, Collins TC, Douglas JD, McIntyre S, Millar J, Carman WF. Virological surveillance of influenza-like illness in the community using PCR and serology. J Clin Virol 2004; 31:40-45.

10. Faria NM, Gianisella Filho J. Prevalência de distúrbios respiratórios e avaliação de vacinação contra a gripe em trabalhadores. Rev Brasil Epidemiol 2002; 5:174-184.

11. Donalisio MR, Ramalheira RM, Cordeiro R. Eventos adversos após vacinação contra influenza em idosos, Distrito de Campinas, SP, 2000. Rev Soc Bras Med Trop 2003; 36:467-471.

12. Fleming DM. Influenza diagnosis and treatment: a view from clinical practice. Philos Trans R Soc Lond B Biol Sci 2001; 356:1933-1943.

13. Meylan P. Respiratory viruses: epidemiological features, clinical impact, and management. Rev Med Suisse Romande 2003; 123:143-150.

14. Greenberg SB. Respiratory viral infections in adults. Curr Opin Pulm Med 2002; 8:201-208.

15. Treanor J, Falsey A. Respiratory viral infections in the elderly. Antiviral Res 1999; 44:79-102.

16. Belongia EA, Shay DK. Influenza vaccine for community-acquired pneumonia. Lancet 2008; 372:352-354.

17. Francisco PMSB, Donalisio MR, Barros MBA, Galvão César CL, Carandina L, Goldbaum M. Fatores associados à vacinação contra a influenza em idosos. Pan Am J Public Health 2006; 19:259-264.

18. Francisco PMSB, Donalisio MR, Barros MBA, Galvão César CL, Carandina L, Goldbaum M. Vacinação contra influenza em idosos por área de residência: prevalência e fatores associados. Rev Bras Epidemiol 2006; 9:162-171.

19. Francisco PM, Barros MB, Cordeiro MR. Influenza vaccination among elders: prevalence, associated factors, and reasons for noncompliance in Campinas, São Paulo State, Brazil. Cad Saude Publica 2011; 27:417-426.

20. Matsuzaki Y, Katsushima N, Nagai Y, Shoji M, Itagaki T, Sakamoto M, et al. Clinical features of influenza C virus infection in children. J Infect Dis 2006; 193:1229-1235.

21. Cação JC, Godoy MRP, Villas Boas PJF. Vacinação em idosos: dados atuais. Anais 30 Congresso Paulista de Geriatria e Gerontologia 2003; Available from: www.emv. unesp.br/PDF/ Vacina\%E7\%E30\%20idoso\%20GERP03.PDF.

22. Puig-Barberà J, Ors Zarzoso P, Vilchez Peña C, Lloria Paes F. Impact of various strategies on the rates of flu vaccination in the elderly. Aten Primaria 1999; 23:339-345.

23. Gulati U, Keitel WA, Air GM. Increased antibodies against unfolded viral antigens in the elderly after influenza vaccination. Influenza Other Respir Viruses 2007; 1:147-156.

24. Trzonkowski P, Myœliwska J, Pawelec G, Myœliwski A. From bench to bedside and back: the SENIEUR Protocol and the efficacy of influenza vaccination in the elderly. Biogerontology 2009; p:83-94.

25. Castle SC, Uyemura K, Rafi A, Akande O, Makinodan T. Comorbidity is a better predictor of impaired immunity than chronological age in older adults. J Am Geriatr Soc 2005; 53:1565-1569.

26. Mac Donald R, Baken L, Nelson A, Nichol KL. Validation of self-report of influenza and pneumococcal vaccination status in elderly outpatients. Am J Prev Med 1999; 16:173-177.

27. Bedford D, Howell F. Influenza vaccination uptake in 1999 and older persons recall of vaccination. Ir Med J 2001; 94:264-265. 